International JOURNAL OF MULtidisciplinary REsearch AND ANALysis

ISSN(print): 2643-9840, ISSN(online): 2643-9875

Volume 05 Issue 02 February 2022

DOI: 10.47191/ijmra/v5-i2-10, Impact Factor: 6.072

Page No.- 303-307

\title{
Conflict on Natural Resources Management in Mimika District: A
}

Review

\section{Apolo Safanpo ${ }^{1}$, Alfred Alfonso Antoh ${ }^{2}$}

${ }^{1}$ Civil Engineering Department, Faculty of Engineering, Cenderawasih University,

2 Biology Education Study Program, Department of Mathematics and Natural Sciences Education, Faculty of Teacher Training and Education, Cenderawasih University, Sentani street, Abepura 99351, Papua Province, Indonesia

ABSTRACT: This scientific paper is based on a literature study that discusses mining and plantation activities that have the potential to reduce the quality of natural resources and the environment. On the other hand, it is necessary to develop the concept of sustainable development so that the damage caused by mining activities, exploitation of forest and land resources for plantation purposes does not pose a widespread threat to the surrounding natural environment. Forest and land degradation due to the massive use of natural resources requires good solutions to find a way out for the loss of biological natural ecosystems. Scientific studies by developing critical thinking in order to find solutions to problems in the field must be found in order to achieve national development, namely improving people's welfare without sacrificing human beings.

KEYWORDS: mining, plantation, forest exploitation, Mimika district

\section{INTRODUCTION}

Development which is a process of change to improve the standard of living of humans cannot be separated from the activities of utilizing natural resources. During this activity, we often encounter human actions that make changes without paying attention to the resulting balance of the ecosystem. The higher the rate of development, the higher the level of utilization of natural resources to be exploited, and the greater the ecosystem changes that occur in the area. Therefore, in planning the development of an ecological system, it is necessary to pay attention to the applicable ecological principles, with the aim of reducing the negative consequences that arise, especially for the development itself.

It is interesting to be discussed in this topic because natural resources are essentially to meet the welfare of the community. On the other hand, forest is a renewable natural resource and Gold is a non-renewable resource. Gold hunting community activities are indeed rife in several places in Timika. As a result of these activities, there have been many changes to the land structure in Timika. The increasing number of mining activities by the community broadly has consequences for the increasing number of green areas that continue to be depressed. Community mining activities that are managed by the community independently in the form of community mining and scavenging gold flakes left over from PT. Freeport Indonesia but some of these activities caused damage to some green areas.

\section{THE CONCEPT OF FOREST AND ITS UNDERSTANDING ACCORDING TO PAPUANS}

The definition of forest according to law number 41 of 1999 concerning the Principles of Forestry defines forest as a field of tree growth which as a whole is an association of living nature and its natural environment and is designated by the government as forest. Even the definition of forest in the law above also has perceptions and views in terms of the interests of regional development in Papua which is reaffirmed in the Special Autonomy Law Number 21/2001 article 43, namely: "opening access for indigenous peoples to manage and utilize their forests can giving excessive meaning to both the government, indigenous peoples and investors (Tokede., 2014).

Based on the definition of forest above, the forest in the management system can be viewed from two sides, namely the economic side and the ecological side. The effectiveness of Permenhut 60/2012 concerning Amendments to Government Regulation No. 10 of 2010 concerning changes in Forest Area Functions is doubtful because the Permenhut cannot give different interpretations of the regulations that are hierarchically above it (Nurrochmat. et al. 2014). These two views are implied and 


\section{Conflict on Natural Resources Management in Mimika District: A Review}

expressed in the definition of forest more specifically for all community interests in managing forest resources. Forest in the perspective and view of indigenous peoples has a different meaning, namely forest is the mother. Forests play an important role in people's lives, especially in applying cultural values in social life (Salose. et al. 2014). Next up is Salosa. et al (2014) concluded in the results of their research that the right strategy to preserve the forest and to accommodate the interests of the community is expected to be based on the wisdom of the community in utilizing the forest.

This forest view can then be the basis for developing the concept of forest management based on indigenous knowledge. Aspects of traditional wisdom by indigenous Papuans vary from one to another, therefore to find the best format it is necessary to identify and find it in the practice of community life to date, for example with hunting techniques, hunting locations, hunting seasons and hunting targets in the forest (Pattiselano.et al. 2014). Pattiselano et al (2014) add that traditional wisdom is a social, political, cultural, economic and environmental system in the life of a local community that is dynamic, sustainable and acceptable.

\section{FOREST MANAGEMENT SYSTEM}

Forest management currently places the community as the subject in implementing a participatory management model. Participatory management is a joint planning process that will characterize a compromise management model (Tyrvainen et al. 2015). One of the causes of low community access to forest use is the construction of policies that are closely tied to the grip of sectoral egoism (Nurrochmat et al. 2014). Next is Nurrochmat. et al. 2014 said that the strong sectoral egoism not only causes biased interests in spatial planning policies, but often also holds the interests of the wider community hostage. Therefore, to ensure the realization of sustainable forest management, a fundamental policy reconstruction of the forest tenure system is needed (Nurrochmat et al. 2014).

On the other hand, there is another opinion that part of natural resource management needs to prioritize the functions and roles of the parties including those who are directly involved in forest management or those who do not have access to unclear management or the emergence of externalities and markets that are not clear. perfect (Grimble \& Wellard. 2015). However, the forest management system requires guidance and direction towards a good management model. For example, a communitybased empowerment is needed through outreach activities, skills training and assistance to the community in the use of mangrove plants as alternative food that can improve family welfare and empowerment to maintain, maintain and preserve mangrove plants (Fitriah. 2015).

Other forest management ideas to lead to success are by establishing relationships with entrepreneurs through academics who are part of the network so as to encourage entrepreneurs' awareness about the importance of the functions and benefits of mangroves for environmental sustainability and the sustainability of shrimp farming and community livelihoods (Febryano et al. 2014) . Next is Febryano. et al (2014) say that the success of local institutions is very helpful for district governments in the development of rural communities in coastal areas.

Meanwhile, other studies also say that the forest resource categorization system in the Nagari Simanau community (processed, stored and prohibited forests) helps control community behavior in managing their forest resources and has good implications for the performance of forest resources, which is indicated by the high density, number of species, species diversity, and tree volume in reserved and prohibited forests (Hamzah et al. 2015).

\section{COMMUNITY RELATIONS WITH FORESTS}

Indonesian people and people in Papua in general have a high level of dependence on forest resources. Forests provide so many broad benefits for the needs of human life. For example: to obtain food sources such as the need for food sources, energy, air and water are provided by the forest. The performance of processed forest is lower, but its economic function as an additional source of livelihood for the community is still maintained. Local institutions that are still trusted and obeyed by the community are effective in supporting good forest resource management. This is indicated by the existence of a management boundary between processed forest, reserves, and prohibitions that have been mutually agreed upon; the existence of rules of the game on the authority to use; and clear sanctions in the enforcement of nagari rules (Hamzah et al. 2015). Another study said that tenure problems in the South Lampung KPH area occurred with the occupation of forest areas by settlements, public or social facilities and shopping centers in the form of a definitive village (Sylvani et al. 2014). Furthermore, Sylvani et al (2014) added that the role of the parties in land tenure in the KPH area is very decisive where the central government that issues policies does not carry out evaluations, especially in area boundaries and inactive permits.

Indigenous peoples are able to protect forests very well within their customary context and understanding of forests (Salose et al. 2014). In the view of the state, it is very, very contrary to the view of indigenous peoples, because there are certain variables and measures that are understood by the state to build its society. For example in a forest management model country with the Timber Legality Verification System (SVLK) which is related to synchronization of rules, coordination, socialization, 


\section{Conflict on Natural Resources Management in Mimika District: A Review}

financial support and guidance for small industries as well as assessment criteria for industries that have diverse raw material sources (Gultom et al. 2014 ). People who live far from the touch of information and communication are considered as marginal communities (untouched by development). So that forest clearing for development in the form of road construction, oil palm plantations or residential development is considered an alternative and a solution to be able to advance the community. The demands and wishes of the government are often not in line with the real conditions faced by the community. Especially the mental readiness of the community to accept change for the sake of change. The government's motivation to open isolation by converting forests can have a psychological impact on the long-standing intimate relationship between the community and the forest.

Sustainable forest management is inseparable from increasing the capacity and standard of living of the community. Cultural and linguistic diversity is also another thing that really needs to be considered in accommodating the concept of sustainable forest management. The relationship between the community and the forest should also be maintained, by providing wise guarantees to keep the relationship between humans and nature in balance. Communities and forests are still seen as a unit in management. Managing the forest means that we also participate in managing the people living around the forest. The conflict resolution offered is to build an effort to "turn conflict into equal partnership", with the following steps: 1) Building trust, 2) Developing an Inter-Village Forestry Forum (FKAD), 3) Preparing a team of experts, 4) Effective communication and 5) mutually agreed regulations (Harun and Dwiprabowo. 2014).

The condition of Papua with so many cultures and languages is unique in itself and at the same time can be a challenge for every stake-holder to participate together in paying attention to forests and their ecosystems. Looking at the natural events that occurred in Wasior, West Papua, the spill of larvae and hot dust bursts in Yogyakarta and the tsunami disaster in Mentawai can provide very valuable lessons for us to look further into our relationship with our nature. Never act after a natural disaster strikes, but it is necessary to think about wise steps as early as possible in managing our natural resources, especially forests.

\section{CONFLICTS OF INTEREST IN MANAGING FORESTS}

The position of our country as a developing country is the main reason for the government to optimally manage natural resources in helping to improve people's welfare. On the other hand, as a result, forest degradation is related to occupation and forest tenure conflicts that occur in various areas. Due to conflicts over forest land tenure and occupation by other parties, HPH companies are not active. This condition has invited attention, recognition, and concern from various parties. (Suharjito. 2014). This condition can encourage the government to be able to maximize the potential of its natural resources to be exploited, including forest resources. Forests can make a significant contribution in increasing the country's foreign exchange and increasing PAD.

A country that is moving to build itself is running in an excessively democratic vehicle. Politically, forests can also be used as the main energy to finance political parties. Many of the excuses for forest exploitation are on individual interests and not forest management for state purposes. Power is inherent and exercised through various mechanisms, processes and social relations where mastery of technology, capital, markets, labor and employment opportunities, knowledge, authority, social identity and social relations (bundle of power) will affect the level of access to resources. The greater the power the actor has, the greater his access to these resources (Febryano et al. 2015). People who live in Papua also feel the atmosphere of conflict in the management of forest resources. Regional leaders, both the Governor, the Papuan People's Representative Council (DPRP) and the Papuan People's Assembly (MRP) should be more observant in looking at this conflict issue. The Governor's policy to limit the export of logs outward greatly suppressed the practice of illegal logging on a large scale.

But on the other hand, whether accurate supervision by competent institutions in the region is well established or is there still illegal logging practices that are still hidden. Therefore, good supervision and coordination between institutions and authorized institutions need to be built in synergizing common interests. The application of a restorative justice approach in conflict resolution is actually the use of traditional patterns with conflict resolution values that exist in local cultural wisdom with a focus on fulfilling victims of justice, through the concepts of equality, partnership, reconciliation and participation (Sukardi 2016).

We need to think about this fact and do an in-depth analysis of the demand for wood in relation to the exploitation activities carried out. Communities as forest owners need to be invited together in managing forests. Therefore, the paradigm shift from government to government which underlies the role of government is reduced and the role of the community is increasingly enhanced cannot be applied to the process of forming a Forest Stakeholder Unit (KPH) in Tanah Papua (Yeny 2014). The dynamic urban development in Papua can force people to hand over their management rights to irresponsible third parties. Is the government ready to recommend forest management systems to the community directly? Capital and Expertise are two sides of a coin that cannot be separated. These two factors can be triggers for a prolonged conflict of interest in managing our forests. 


\section{Conflict on Natural Resources Management in Mimika District: A Review}

\section{IMPACT OF LAND USE ACTIVITIES ON BIOLOGICAL ECOSYSTEMS}

These biological and non-biological components are functionally related to each other and interact with each other to form a system that we often refer to as an ecological system. If there is a change in one of these components, it will be able to affect the entire system in the ecosystem. The sustainability of an ecosystem function greatly affects the sustainability of natural resources as components involved in the system, therefore to ensure the sustainability of natural resources we need to pay attention to the ecological relationships that take place between the components of these resources (Mohri et al. 2013).

The forest in Timika is dominated by swampy forest vegetation, but also a lot of forest on dry land. This community mining activity is indeed very difficult to control by the local government, in this case the Mimika Regency mining office. In terms of contours and topography as well as land suitability analysis, many can be developed into plantation areas. The plantation that is quite developed is Palm Oil. Exploitation activities on natural resources and the environment are carried out individually but also carried out in a corporate manner by involving local governments and third parties in this case the private sector. All of these activities are oriented towards increasing Regional Original Income (PAD). This justification has always been the basis for those in authority. But the facts on the ground show that there has been disorientation so that the main goal is not in accordance with the facts found in the field.

The increase in dry land from mining activities but also the clearing of plantation areas also contributed greatly to the effects of drought and consequently to land marginalization. Marginal lands cause unproductive land to be used for the long term. Planning for the management of forest and land resources is an important agenda that must be agreed together for the sustainability of benefits for the community in the future.

\section{THE CONCEPT OF CONSERVING NATURAL RESOURCES}

The concept of sustainable forest is strongly encouraged by the current government at the central level. The joining of the Ministry of Forestry and Environment has a special mission to save forests and land. For this reason, evaluation of the utilization of natural resources, both minerals and forest conversion activities for plantation activities in Timika, needs attention from the local government. The food and energy crisis that is currently being felt by our nation, therefore anticipatory steps to this situation need to be followed up (Ogwu et al. 2014). Cooperation between local governments and higher education institutions to NonGovernment Organizations (NGOs) has produced a number of studies but it seems that all of these things have not fully become a roadmap for sustainable development.

The increasing damage to productive lands in Mimika Regency needs to teach a big lesson for all parties to organize and manage forest and land resources more carefully. The long-term implications can have a big impact on the community in Timika in particular but also in Papua in general. The orientation of forestry and environmental development requires that we need to accommodate the principles of sustainable development. When forests and the environment are sustainable, our society will be able to enjoy it in the future.

\section{CONCLUSION}

Monitoring and evaluation activities on land and forest use activities are important to be carried out by the government but the private sector in this case invests. The importance of monitoring land use forest activities is an important part that is not considered. Monitoring land use activities will protect our natural resources so that they can be sustainable.

\section{ACKNOWLEDGEMENTS}

Thank you to the relevant stakeholders for the discussion and sharing in sharpening scientific writing so that it is hoped that it will be useful for anyone who reads it.

\section{REFERANCES}

1) Fauzi A., 2015. Valuasi Ekonomi dan Penilaian Kerusakan Sumber Daya Alam dan Lingkungan. IPB Press. Bogor

2) Febryano IG., Didik Suharjito, Dudung Darusman, Cecep Kusmana. 2015. Aktor dan Relasi Kekuasaan dalam Pengelolaan Mangrove di Kabupaten Pesawaran Provinsi Lampung Indonesia. Jurnal Analisis Kebijakan Kehutanan. Vol.12.No.2, Agustus 2015: 123-138

3) Harun MK., Hariyatno Dwiprabowo. 2014. Model Resolusi Konflik Lahan di Kesatuan Pemangku Kehutanan Produksi Model Banjar. Jurnal Penelitian Sosial dan Ekonomi Kehutanan.Vol.11 No.4, Desember 2014: 265-280

4) Fitriah E. 2015. Analisis Presepsi dan Partisipasi Masyarakat Pesisir dalam Pemanfaatan Tumbuhan Mangrove sebagai Pangan Alternatif untuk Menghadapi Ketahanan Pangan. Jurnal Scientiae Educatia. Vol 5,No.2 Tahun 2015 :93-112 


\section{Conflict on Natural Resources Management in Mimika District: A Review}

5) Grimble R and Kate Wellard. 2015. Stakeholder Methodologies in Natural Resource Management: a Review of Principles, Contexts, Experiences and Opportunities. Agricultural System Journal, Vol.55, No.2: 173-193

6) Gultom M., Satria Astana, Rachman Effendy \& Andri Setiadi Kurniawan. 2014. Sistem Verifikasi Legalitas Kayu dan Perbandingannya dengan Sertfikasi Sukarela Pada Level Industri. Jurnal Analisis Kebijakan Kehutanan. Vol.11, No.3: Desember 2014: 261-275

7) Hamzah H., Didik Suharjito., Istomo Istomo. 2015. Efektivitas Kelembagaan lokal dalam Pengelolaan Sumber Daya Hutan pada Masyarakat Nagari Simanau Kabupaten Solok.Jurnal Risalah Kebijakan Pertanian dan Lingkungan. Rumusan Kajian Strategis Bidang Pertanian dan Lingkungan. Volume 2 Nomor 2 Tahun 2015.

8) Innah HS., Arya Hadi Dharmawan, Didik Suharjito \& Dudung Darusman. 2012. Peran Dinamika Jejaring-Aktor Dalam Konteks Reforestasi di Papua. Jurnal Penelitian Sosial Ekonomi Kehutanan Vol.9 No.2 Juni 2012, Hal.96-112

9) Kartodiharjo H., 2015. Arti dan Lingkup Kelembagaan. Bahan Bacaan-MNH722. Tidak Diterbitkan.

10) Kartodiharjo H., 2008. Dibalik Kerusakan Hutan \& Bencana Alam. Masalah Transformasi kebijakan Kehutanan. Penerbit Wahana Aksara. Tangerang Banten.

11) Kartodiharjo H., 2006. Masalah Kepastian Kelembagaan dan Arah Kebijakan Kehutanan: Studi Tiga Kasus. Jurnal Manajemen Hutan Tropika Vol.XII No.3:14-25

12) Mohri H, Shruti Lahoti, Osamu saito, Anparasan Mahalingam, Nimal Gunatilleke, Irham, Van Thang Hoang, Gamini Hitinayake, Kazuhiko Takeuchi, Srikantha Herath., 2013, Assesment of ecosystem services in homegarden systems in Indonesia, Sri Lanka and Vietnam. Ecosystem Services. 5:124-136.

13) Ogwu MC., NE Osawaru., AO. Chime., 2014, Comparative Assesment of Plant Diversity and Utilization Patterns of Tropical Homegardens in Edo State, Nigeria. Scientia Africana. 13 (2):146-162.

14) Nurrochmat DR., Dudung Darusman, Deddy Ruchjadi. 2014. Rekonstruksi Sistem Tenurial Kehutanan. Jurnal Risalah Kebijakan Pertanian dan Lingkungan Vol.1 No.1, April 2014: 24-29

15) Pattiselanno F., Jacob Manusawai, Agustina Y.S. Arobaya dan Herman Manusawai. 2015. Pengelolaan dan Konservasi Satwa Berbasis Kearifan Tradisional Di Papua. Jurnal Manusia dan Lingkungan, Vol.22, No.1, Maret 2015:106-112

16) Salosa ST., San Afri Awang, Priyono Suryanto, Ris Hadi Purwanto. 2014. Hutan dalam Kehidupan Masyarakat Hatam Di Lingkungan Cagar Alam Pegunungan Arfak. Jurnal Manusia dan Lingkungan, Vol.21,No.3,November 2014:349-355

17) Suharjito D., 2014. Devolusi Pengelolaan Hutan dan Pembangunan Masyarakat Pedesaan. Orasi Ilmiah. Tidak Diterbitkan. IPB. Bogor

18) Sukardi., 2016. Penangan Konflik Sosial dengan Pendekatan Keadilan Restoratif. Jurnal Hukum \& Pembangunan 46 No.1 (2016): 70-89 E-ISSN: 2503-1465 (online)

19) Sylvani., Hariyatno Dwiprabowo, Elvrida Yosefi Suryandari., 2014. Kajian Kebijakan Penguasaan Lahan dalam Kawasan Kesatuan Pengelolaan Hutan (KPH). Jurnal Analisis Kebijakan Kehutanan. Vol.11 No.1, April 2014: 54-70

20) Tokede M., 2014. Mengelola Hutan Alam Lestari Berkeadilan: Implementasi Paradigma Hutan untuk Kesejahteraan Masyarakat Adat.(Edisi Revisi). Unipa Press. Manokwari

21) Tyrväinen L., Harri Silvennoien and Osmo Kolehmainen., 2015. Ecological and aesthetic values in Urban Forest Management. Urban For.Urban Green.1 (2015): 135-149

22) Yeny I., 2014. Para Pihak dan Perannya dalam Pembangunan KPH Model di Tanah Papua. Jurnal Analisis Kebijakan Kehutanan. Vol 11. No.3; Desember 2014: 193-206

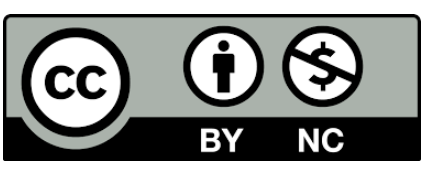

There is an Open Access article, distributed under the term of the Creative Commons Attribution - Non Commercial 4.0 International (CC BY-NC 4.0)

(https://creativecommons.org/licenses/by-nc/4.0/), which permits remixing, adapting and building upon the work for non-commercial use, provided the original work is properly cited. 